\title{
Inhibition of Fungal Growth and Fusarium Toxins by Selected Cultures of Lactic Acid Bacteria
}

\author{
Nanis H Gomah ${ }^{1 *}$ and Abdel Naser A Zohri ${ }^{2}$ \\ ${ }^{1}$ Dairy Department, Faculty of Agriculture, Assiut University, Egypt \\ ${ }^{2}$ Botany and Microbiology Department, Faculty of Science, Assiut University, Egypt
}

\begin{abstract}
Two species of Lactobacilli (Lactobacillus rhamnosus and Lactobacillus paracasie subsp. paracasie) were tested for their ability to inhibit growth and mycotoxins production by three species of Fusarium, (F. graminearum, $F$. culmorum and $F$. proliferation) which are the main producers of mycotoxins deoxynivalenol, zearalenone and fumonisin B1, respectively. L. paracasie subsp. paracasie was found to be effective in reducing the amount of toxins produced, although fungal growth was not affected. The inhibition levels of Deoxynivalenol, Zearalenone and Fumonisin B1 production reached to $56.8,73.0$ and $76.5 \%$, respectively. Meanwhile, L. rhamnosus showed the highest inhibitory activity against both fungal growth and mycotoxins production. It completely suppressed mycelium growth of all the studied Fusarium species and consequently, no toxin was produced in the presence of this bacterium. The obtained results confirm that, selected species of Lactic acid bacteria may be successfully used as a biological control agent of food contamination with molds and mycotoxins. This bio-preservation action has interesting technological possibilities for a variety of fermented food and dairy products.
\end{abstract}

Keywords: Inhibition; Fusarium; Lactic acid bacteria; Deoxynivalenol; Zearalenone; Fumonisin B1

\section{Introduction}

Fusarium is one of the most important genera of plant pathogenic fungi, with a record of devastating infections in various economically important plants [1]. Certain species of fusaria are capable of producing mycotoxins which can be accumulating in the infected plants and stored materials. The International Agency for Research on Cancer [2] has grouped the main Fusarium mycotoxins on the basis of the fungal producing them as it represents the best way for identify the real situation through which humans become exposed to these naturally occurring toxins. Therefore, the most important mycotoxins, in terms of natural occurrence and toxicology, have been grouped in: toxins derived from F. sporotrichioides (T-2 toxin and related trichothecenes), toxins derived from F. graminearum, F. culmorum and F. crookwellense (Deoxinivalenol, Nivalenol, Fusarenone and Zearalenone), and toxins derived from $F$. moniliform (Fumonisins and Fusarine C). Only the group of toxins deriving from $F$. moniliform was identified as group $2 \mathrm{~B}$, i.e. possible carcinogenic to humans and with sufficient evidence of carcinogenicity towards experimental animals, whereas the data relevant to the other groups of toxins or to individual toxins were not sufficient (or adequate) to make them classifiable as to their carcinogenicity to humans [2].

Deoxynivalenol (DON) is a mycotoxin produced by F. graminearum and F. culmorum, which are abundant in various cereal crops (wheat, corn, barley and oats) and processed grains (malt, beer and bread). Chemically, it belongs to trichothecenes and is a very stable compound, both during storage/milling and the processing/cooking of food and it does not degrade at high temperatures [3]. DON inhibits the synthesis of DNA, RNA and protein synthesis at the ribosomal level. The toxin has hemolytic effect on erythrocytes. An acute dose of DON can induce vomiting in pigs, whereas at lower concentrations in the diet it reduce growth and feed consumption [4].

Zearalenone is a secondary metabolite produced mainly by $F$. culmorum. It possesses strong estrogenic activity and can result in severe reproductive and infertility problems when they are fed to domestic animals in sufficient amounts. Swine appears to be the most sensitive of the domestic animals species, therefore the most frequently reported with problems caused by zearalenone, which include enlargement or swilling and reddening of the vulva in gilts and sows (vulvovaginitis), swelling of the mammary glands and atrophy of the ovaries, vaginal and rectal prolaspses. In young male it can cause swelling of the prepuce, testicular atrophy, enlargement of the mammary glands, while in boars it causes reduced libido and a marginal reduction in sperm quality. Effects in other species are much less pronounced. High concentrations of zearalenone have been associated with infertility and development of a typical secondary sexual characteristic in heifers [5].

Fumonisins are structurally related mycotoxins produced mainly by $F$. verticilloides and $F$. proliferatum, both of which are frequently found in corn worldwide [6,7]. Of the several fumonisins identified, fumonisin $\mathrm{B} 1$ (FB1) is considered to be the most abundant and the most toxic [7]. FB1 has been associated with several fatal diseases in animals, including Equine Leuko encephalomalacia [8]. FB1 has also been demonstrated experimentally to be hepatotoxic and hepato carcinogenic in rats [6]. Epidemiological data also indicate a possible correlation between the consumption of fumonisin/F. verticillioides contaminated corn and the high incidence of esophageal cancer in countries where corn is a dietary staple [9-11].

Although the prevention of mycotoxin contamination of grain is the main goal of food and agricultural industries throughout the world, under certain environmental conditions the contamination

\footnotetext{
*Corresponding author: Nanis H Gomah, Dairy Department, Faculty of Agriculture, Assiut University, Egypt, Tel: +201221764655; E-mail: nanis2000eg@yahoo.com
}

Received July 28, 2014; Accepted September 10, 2014; Published September 17, 2014

Citation: Gomah NH, Zohri ANA (2014) Inhibition of Fungal Growth and Fusarium Toxins by Selected Cultures of Lactic Acid Bacteria. J Microbial Biochem Technol S7: 001. doi:10.4172/1948-5948.S7-001

Copyright: @ 2014 Gomah NH, et al. This is an open-access article distributed under the terms of the Creative Commons Attribution License, which permits unrestricted use, distribution, and reproduction in any medium, provided the original author and source are credited 
of various cereal grains with Fusarium fungi and mycotoxins are unavoidable for grain producers. Several strategies have been applied to eliminate mold growth and mycotoxins production or to remove/ destroy the preformed toxins from grains and foodstuffs $[12,13]$. The ideal decontamination procedure should be easy to use, inexpensive and should not lead to the formation of compounds that are still toxic or can alter the nutritional and palatability properties of the food. Chemical antifungal agents have long been used to control fungi in foods [12-15]. In some situations, the prolonged use or overuse of these chemicals has led to the development of fungal resistance. Also, the levels of chemicals used in the food industry are fungistatic and do not kill or completely inhibit growth of an indefinite time [15]. However, increasing consumer concerns about chemicals in foods has led to interest in novel presentation methods. It has been reported that antagonistic microorganisms or their antimicrobial metabolites have some potential as natural bio preservatives to control undesirable fungi. Mold growth and mycotoxins production are inhibited by antifungal metabolites produced by lactic acid bacteria [16-18] and some Bacillus sp. [19-21]. Recently, Nanis [22] and Chelkowski [1] demonstrated that some lactic acid bacteria and yeast species have promising ability as natural food-grade bio control agents of mold growth and mycotoxin production.

The present study was aimed to investigate the ability of both Lactobacillus rhamnosus and L. paracasie subsp. Paracasie to: (a) inhibits growth of three toxigenic Fusarium species i.e. F. graminearum R6574, F. proliferatum M 5991 and F. culmorum R 5321 and (b) prevents the formation of the mycotoxins deoxynivalenol, zearalenone and fumonisin B1 by the over mentioned Fusarium species.

\section{Materials and Methods}

\section{Microbial cultures}

The lactic acid bacteria used in this study were Lactobacillus rhamnosus and L. paracasie subsp. paracasie obtained from the Culture Collection of the Department of Food Science and Technology at Nebraska University, Nebraska-Lincoln, USA.

Fungal cultures of F. graminearum R6574, F. proliferatum M 5991 and F. culmorum R 5321 were obtained from the Fusarium research center at Pennsylvania State University, University Park, PA., US.

\section{Inoculum preparation}

Frozen stock cultures of Lactic acid bacteria were prepared by thawing under optimum temperature, activated in litmus milk. Then, cultured in de Man Rogosa Sharpe (MRS) broth and incubated at $37^{\circ} \mathrm{C}$ for $24 \mathrm{~h}$ before use. Spore suspensions of molds, grown on carnation leaf agar slants for 14 days prior to the experiment, were prepared by washing the slants with $10 \mathrm{ml}$ of sterilized solution of tween $80(0.5 \%$ $\mathrm{V} / \mathrm{V}$ ), then the spores were loosened by gentle brushing with sterile spatula. Mycelium debris was removed by filtration through sterile cheese cloth. Spores count in the resulting suspension was determined by Petroff-Houser counting chamber [23]. Spores count was finally adjusted to $10^{7}$ spores of each fungus per $\mathrm{ml}$ and stored at $4^{\circ} \mathrm{C}$ until use.

\section{Antifungal activity assay}

This assay was a modification of the overlay technique described by [24]. Three $5 \mu \mathrm{l}$ drops from an active culture of each bacterial strains tested were spotted into agar plates and incubated until well- grown colonies could be observed (Ca. 24-48 h). The plates then were overlaid with $10 \mathrm{ml}$ of Glucose Yeast Extract Agar (GYA) medium, on which 0.1 $\mathrm{ml}$ of a mold spore suspension $\left(10^{7}\right.$ spores per $\left.\mathrm{ml}\right)$ was finally spread out. After incubation for up to 5 days, the plates were examined for a halo zone formation around the bacterial colonies. These experiments were performed in triplicate.

\section{Inhibition of mycotoxin production}

The ability of Lactobacillus rhamnosus and Lactobacillus paracasie sub sp. paracasie strains to inhibit production of deoxynevalenol, fumonisin B1 and zearalenone by the investigated fungi was examined by the simultaneous antagonism assay as described by [21]. Hundred $\mathrm{ml}$ portions of glucose yeast extract broth medium were sterilized at $121^{\circ} \mathrm{C}$ for $15 \mathrm{~min}$ in $250 \mathrm{ml}$ Erlenmeyer flasks. Each flask was inoculated with $1 \mathrm{ml}$ of fungal spores' suspension containing $10^{7}$ spores $/ \mathrm{ml}$, and $1 \mathrm{ml}$ containing $10^{7}$ Cells of bacterial culture grown at $30^{\circ} \mathrm{C}$ for $24 \mathrm{~h}$ in MRS medium without acetate. All flasks were incubated at $28^{\circ} \mathrm{C}$ and analyzed for toxin production after 10, 15 and 20 days of incubation. Mycelium growth inside flasks was visually determined as indication of growth rate or growth inhibition.

\section{Determination of deoxynivalenol}

At the end of the incubation period, the deoxynivalenol content was extracted by adding $50 \mathrm{ml}$ of $\mathrm{MeOH}: \mathrm{H}_{2} \mathrm{O}$ (84:16) in Erlenmeyer flasks and shaken for $1.5 \mathrm{~h}$ at room temperature $\left(25^{\circ} \mathrm{C}\right)$. Extracts $(10$ $\mathrm{ml}$ ) were filtered and $6 \mathrm{ml}$ of filtered extract were cleaned up using Mycosep columns (Coring System Diagnostix GmbH, Gernsheim/ Rhein, Germany). Two ml of cleaned extract were transferred to round bottom flasks and evaporated to dryness). The dried extracts were redissolved in $500 \mu \mathrm{l}$ aqueous $12.5 \% \mathrm{MeOH}$, transferred to $0.8 \mathrm{ml}$ glass vials and stored at $-70^{\circ} \mathrm{C}$ until analysis [15]. Deoxynivalenol contents of the extracts were determined by comparison with standards (Supelco, Bellefonte, PA, USA) using a High Performance Liquid Chromatography (HPLC) as described by Stiles [28] and Bullerman [15]. The system consisted of a model 510 HPLC pump and a U6K loop injector (Waters Associates, Milford, MA), a high speed reverse phase column $(\mathrm{C} 18,4.6 \mathrm{~mm} \times 33 \mathrm{~mm}, 3 \mu \mathrm{m}$ particle size, perkin-Elmer Corp., Norwalk, CT), and a model 474 scanning fluorescence detector (Waters, Milford, MA). All chromatographic analysis were monitored with computer millennium software (version 2.15, Waters Associates, Milford, MA), connected to the HPLC instruments. Fumonisin B1 was quantified by correlating peak area of the extract to that of reference standard. The entire experiment was repeated three times in duplicate.

\section{Fumonisin B1 and zearalenone assay}

The contents of each flask were extracted with $50 \mathrm{ml}$ of acetonitrile: water $(50: 50, \mathrm{~V} / \mathrm{V})$ for $60 \mathrm{~min}$ using a wrist-action shaker (Burrell Corp., Pittsburgh, PA). The extracts were filtered through Whatman No.1 filter paper and then $2 \mathrm{ml}$ extracts were purified with a solid phase extraction column (C18, Sep-Pak cartridge, Waters Association, Milford, MA). Before loading the sample, the SPE column was connected to a $10 \mathrm{ml}$ syringe barrel and conditioned with $2 \mathrm{ml}$ of acetonitrile, and $2 \mathrm{ml}$ of $1 \% \mathrm{KCI}$ solution. The $2 \mathrm{ml}$ of filtered extract was pipetted into the barrel of the syringe and diluted by adding $6 \mathrm{ml}$ of $1 \% \mathrm{KCI}$. Diluted sample was then loaded onto the column at a flow rate of $1 \mathrm{ml} / \mathrm{min}$, facilitated by a vacuum manifold (Visiprep, Supelco, Inc., Bellefonte, PA). The column was washed with $2 \mathrm{ml}$ of $1 \% \mathrm{KCI}$ followed by $2 \mathrm{ml}$ of acetonitrile: water $(15: 85, \mathrm{~V} / \mathrm{V})$, followed by air forced through the column. Fumonisin B1 was eluted with $2 \mathrm{ml}$ of acetonitrile: water (70: 30, V/V). Fumonisin B1 and zearalenone levels were determined with competitive direct Enzyme-Linked Immunosorbent Assay (ELISA) test kits (Veratox, Neogen Corp., Lansing, Mich.) in accordance with the kit instructions $[25,26]$. 


\section{Results and Discussion}

The antifungal activities of both $L$. paracasie sub sp. paracasie and Lactobacillus rhamnosus against each of $F$. graminearum R6574, F. proliferatum M 5991 and F. culmorum R 5321 are shown in Tables 1-3. Control treatments in all experiments revealed that all the studied molds were extensively grown and produced high levels of their mycotoxins when cultivated individually in the absence of the antagonistic bacteria. Concentrations of all mycotoxins markedly increased with increasing the incubation period from 10 to 20 days. Data in Table 1 showed that, when fungus $F$. graminearum was grown simultaneously with L. paracasie sub sp. Paracasie, mycelium growth was slightly affected butdeoxynevalenol production was reduced by about $45.2 \%$ and $56.8 \%$ after 10 and 20 days of incubation, respectively. At the same time, cultivation of F. graminearum in the presence of L. rhamnosus resulted in complete inhibition of bothmycelium growth and deoxynevalenol production.

Data presented in Tables 2 and 3 indicated that $L$. paracasie sub sp. paracasie partially inhibited production of zearalenone and fumonisin B1 by F. culmorum and F. proliferatum although mycelium growth of both fungi was not affected. Percentages of inhibition of, zearalenone production were 57.4 and $73.0 \%$ of that produced in the control treatment after incubation periods of 10 and 20 days, respectively (Table 2). Meanwhile, fumonisin B1 production was inhibited by about $61.5 \%$ and $76.5 \%$ after 10 and 20 days of incubation, respectively (Table 3). On the other hand, Lactobacillus rhamnosus showed the highest antifungal as well as, antimycotoxigenic effects, it completely suppressed growth of F. culmorum and $F$. proliferatum, and hence no zearalenone or fumonisin B1 was formed (Tables 2 and 3).

Results of the present study are in agreement with that recorded by other investigators [16,22,27-30] who described the antifungal properties of different lactic acid bacteria against fungal contamination of dairy and food products. El-Nezami and Ahokas, Peltonen et al. and Haskard et al. $[18,32,33]$ reported that $L$. rhamnosus strains removed

\begin{tabular}{|c|c|c|c|c|}
\hline Bacterial strain & $\begin{array}{c}\text { Incubation } \\
\text { period (days) }\end{array}$ & $\begin{array}{c}\text { Mold growth } \\
\text { (visual) }\end{array}$ & $\begin{array}{c}\text { DON conc. } \\
\text { (ppm) }\end{array}$ & $\begin{array}{c}\text { DON } \\
\text { inhibition } \\
\text { (\%) }\end{array}$ \\
\hline Control & 10 & +++ & 69.2 & - \\
\hline \multirow{2}{*}{$\begin{array}{c}\text { L. paracasie subsp. } \\
\text { paracasie }\end{array}$} & 20 & +++ & 481.6 & - \\
\hline \multirow{2}{*}{ L. rhamnosus } & 10 & ++ & 37.9 & 45.2 \\
\hline & 20 & ++ & 208.1 & 56.8 \\
\hline
\end{tabular}

Legend: (-) no mold growth, $(+)$ weak growth, $(++)$ moderate growth, $(+++)$ strong growth, (ND) not detected.

Table 1: Effect of L. paracasie subsp. Paracasie and Lactobacillus rhamnosus on growth of $F$. graminearum R6574 and Deoxynivalenol production.

\begin{tabular}{|c|c|c|c|c|}
\hline Bacterial strain & $\begin{array}{c}\text { Incubation } \\
\text { period (days) }\end{array}$ & $\begin{array}{c}\text { Mold growth } \\
\text { (visual) }\end{array}$ & $\begin{array}{c}\text { Zearalenone } \\
\text { conc. (ppm) }\end{array}$ & $\begin{array}{c}\text { Zearalenone } \\
\text { inhibition (\%) }\end{array}$ \\
\hline \multirow{2}{*}{ Control } & 10 & +++ & 3300 & - \\
\cline { 2 - 5 } & 20 & +++ & 4900 & - \\
\hline \multirow{2}{*}{$\begin{array}{c}\text { L. paracasie } \\
\text { subsp. paracasie }\end{array}$} & 10 & +++ & 1405 & 57.4 \\
\hline \multirow{2}{*}{ L. rhamnosus } & 20 & +++ & 1322 & 73 \\
\cline { 2 - 5 } & 10 & - & ND & 100 \\
\hline
\end{tabular}

Legend: (-) no mold growth, $(+)$ weak growth, $(++)$ moderate growth, $(+++)$ strong growth, (ND) not detected

Table 2: Effect of $L$. paracasie subsp. Paracasie and Lactobacillus rhamnosus on growth of F. culmorum R 5321 and Zearalenone production.

\begin{tabular}{|c|c|c|c|c|}
\hline Bacterial strain & $\begin{array}{c}\text { Incubation } \\
\text { period (days) }\end{array}$ & $\begin{array}{c}\text { Mold growth } \\
\text { (visual) }\end{array}$ & $\begin{array}{c}\text { Fumonisin B1 } \\
\text { conc. (ppm) }\end{array}$ & $\begin{array}{c}\text { Fumonisin B1 } \\
\text { inhibition (\%) }\end{array}$ \\
\hline \multirow{2}{*}{ Control } & 10 & ++ & 200 & - \\
\cline { 2 - 5 } & 20 & +++ & 300 & - \\
\hline \multirow{2}{*}{$\begin{array}{c}\text { L. paracasie } \\
\text { subsp. paracasie }\end{array}$} & 10 & ++ & 77 & 61.5 \\
\hline \multirow{2}{*}{ L. rhamnosus } & 20 & +++ & 70.5 & 76.5 \\
\cline { 2 - 5 } & 10 & - & ND & 100 \\
\hline
\end{tabular}

Legend: (-) no mold growth, $(+)$ weak growth, $(++)$ moderate growth, $(+++)$ strong growth, (ND) not detected.

Table 3: Effect of $L$. paracasie subsp. Paracasie and Lactobacillus rhamnosus on growth of $F$. proliferatum M 5991 and Fumonisin $B_{1}$ production.

54.6 and $80.0 \%$ of aflatoxin B1, while L. lactis and L. casei removed 59.0 and $21.8 \%$ of aflatoxin B1, respectively. El-Nezami et al. [34] demonstrated that strains of $L$. rhamnosus have the ability to remove $55.0 \%$ of zearalenone and its derivative a-zearalenol with a rapid reaction instantly after mixing with the bacteria.

Our results clearly showed that L. rhamnosus is completely suppressed mycelial growth of all the studied molds, consequently no toxin was formed in the presence of this bacterial strain. On the other hand, $L$. paracasie subsp. paracasie mostly did not affect mold growth but reduced mycotoxin concentrations by about $56.8,73.0$ and $76.5 \%$ for Deoxynivalenol, Zearalenone and Fumonisin B1, respectively. This reduction may be explained on the basis of some degradation or removal of the preformed toxins was occurred by the bacterial cells. This postulation is in accordance with that demonstrated by [35]. They found that some lactic acid bacteria have potential to bind aflatoxins, and this binding is a physical phenomenon that is associated with the bacterial cell wall. Morotomi and Mutai [36] suggested that the binding of mutagens to lactic acid bacteria cell wall may occur through cationic binding. Also, Tanabe et al. [37] suggested that such binding may take place through the cell wall peptidoglycan. Furthermore Kollarczik et al. [38] found that zearalenone and deoxynevalenol were degraded in vitro by the normal bacterial gut flora from the distal section of the gastrointestinal tract of pigs. Deoxynevalenol was deep oxidated and zearalenone was hydrolyzed to a-zearalenol and an unknown metabolite.

In conclusion, the use of antifungal lactic acid bacteria instead of chemical preservatives would enable to produce organic foods without addition of chemical substances. In addition to the already known excellent properties of lactic acid bacteria they could enhance the nutritional value and prolong conservation of foods and dairy products.

\section{References}

1. Chelkowski J (1989) Fusarium-Mycotoxins, Taxonomy and Pathogenicity Elsevier, Amsterdam.

2. IARC (1993) Monographs on the evaluation of carcinogenic risks to humans Vol 56. Some naturally occurring substances: Food Items and constituents, heterocyclic aromatice amines and mycotoxins, IARC, Lyon, France, 599.

3. Eriksen GS, Alexander J (1998) Fusarium toxins in cereals- a risk assessment Copenhagen: Nordic council of Ministers. TemaNord 1998:502.

4. Rotter BA, Prelusky DB, Pestka JJ (1996) Toxicology of deoxynivalenol (vomitoxin). J Toxicol Environ Health 48: 1-34.

5. Prelusky DB, Rotter BA, Rotter RG (1994) Toxicology of mycotoxins. Mycotoxins in grain. Edited by Miller JD and Trenholm HL (St Paul: Eagan) pp 359-400.

6. Gelderblom WC, Jaskiewicz K, Marasas WF, Thiel PG, Horak RM, et al. (1988) Fumonisins--novel mycotoxins with cancer-promoting activity produced by Fusarium moniliforme. Appl Environ Microbiol 54: 1806-1811.

7. Nielsen MS, Frisvad JC, Nielsen PV (1998) Protection by fungal starters against 
Citation: Gomah NH, Zohri ANA (2014) Inhibition of Fungal Growth and Fusarium Toxins by Selected Cultures of Lactic Acid Bacteria. J Microbial Biochem Technol S7: 001. doi:10.4172/1948-5948.S7-001

growth and secondary metabolite production of fungal spoilers of cheese. Int $J$ Food Microbiol 42: 91-99.

8. Kellerman TS, Marasas WF, Thiel PG, Gelderblom WC, Cawood M, et al (1990) Leukoencephalomalacia in two horses induced by oral dosing of fumonisin B1. Onderstepoort J Vet Res 57: 269-275.

9. Sydenham EW, Shephard GS, Thiel PG, Marasas WFO, Rheeder JF, et al. (1993) Fumonisins in Argentinean field trial maize. J Agric Food Chem 41: 891 895

10. Chu FS, Li GY (1994) Simultaneous occurrence of fumonisin B1 and othe mycotoxins in moldy corn collected from the People's Republic of China in regions with high incidences of esophageal cancer. Appl Environ Microbiol 60: 847-852.

11. Doko MB, Rapior S, Visconti A, Schjoth JE (1995) Incidence and levels of fumonisin contamination in maize genotypes grown in Europe and Africa. $J$ Agric Food Chem 43: 429- 434

12. Bullerman LB, Schroeder L, Park K (1984) Formation and control of mycotoxins in food. J Food Prot 47: 637-646.

13. Angelo V (2000) Problems associated with Fusarium mycotoxins in cereals. CNR V le L Einaudi 51: 1

14. Brul S, Coote $P$ (1999) Preservative agents in foods. Mode of action and microbial resistance mechanisms. Int J Food Microbiol 50: 1-17.

15. Bullerman LB (2000) Mold growth in bakery products and its prevention. Tech Bull Am Inst Baking 22: 1-8.

16. El-Gendy SM, Marth EH (1981) Growth of toxigenic and nontoxigenic aspergergilli and penicillia at different temperatures and in the presence of lactic acid bacteria. Archiev für Laben smittel hygiene 31: 189-220.

17. Batish VK, Grover S, Lal R (1989) Screening lactic starter culture for antifungal activity. Cultured Dairy Products J 24: 21-25.

18. El-Nezami H, Ahokas J (1998) Lactic acid bacteria: an approach for detoxification of aflatoxins. In Lactic Acid Bacteria Microbiology and Functional Aspects, 2nd edn. ed. Salminen S and von Wright A pp. 359-367. New York: Marcel Dekker.

19. Krebs B, Junge H, Okhardt A, Hoding B, Heubner D, et al. (1993) Bacillus subtilus: An effective biocontrol agent. Pestiside Sci 37: 427-433.

20. Leifert C, Li H, Chidburee S, Hampson S, Workman S, et al. (1995) Antibiotic production and biocontrol activity by Bacillus subtilis CL27 and Bacillus pumilus CL45. J Appl Bacteriol 78: 97-108

21. Munimbazi C, Bullerman LB (1998) Isolation and partial characterization of antifungal metabolites of Bacillus pumilus. J Appl Microbiol 84: 959-968.

22. Nanis GH (2012) Biocontrol of both Fusarium growth and their mycotoxins production using some L. plantarum strains. 1st Int. Conference on Biotechnol 18-22 Feb. 2012, Benha Univ., Egypt.

23. Gourama H (1997) Inhibition of growth and mycotoxin production of penicillium by Lactobacillus species. Lebensmittel Wissenschaft und Technolge 30: 279283.

24. Cabo ML, Braber AF, Koenraad PM (2002) Apparent antifungal activity of several lactic acid bacteria against Penicillium discolor is due to acetic acid in the medium. J Food Prot 65: 1309-1316.

25. Rice LG, Ross PF, Dejong J, Plattner RD, Coats JR (1995) Evaluation of a liquid chromatographic method for the determination of fumonisins in corn, poultry feed, and Fusarium culture material. J AOAC Int 78: 1002-1009.
26. Schollenberger M, Suchy S, Jara HT, Drochner W, Müller HM (1999) A survey of Fusarium toxins in cereal-based foods marketed in an area of southwest Germany. Mycopathologia 147: 49-57.

27. Suzuki I, Nonura M, Morichi T (1991) Isolation of Lactic acid bacteria which suppress mold growth and show antifungal action. Milchwissenshaft 46: 635 639

28. Stiles J, Plockova M, Toth V, Chumchalova V (1999) Inhibition of Fusarium sp. DNF by Lactobacillus strains grown in MRS and Elliker Broths. Advances in Food Science 21: 117-121.

29. Lavermicocca P, Valerio F, Evidente A, Lazzaroni S, Corsetti A, et al. (2000) Purification and characterization of novel antifungal compounds from the sourdough Lactobacillus plantarum strain 21B. Appl Environ Microbiol 66: 4084-4090.

30. Gomah NH, Ragab WS, Bullerman LB (2009) Inhibition of fungal growth and aflatoxin B1 production by some Lactobacillus Strains. Assiut J of Agric Science 40: 27-36.

31. Abdel-kareem MM (2014) Biocontrol of some toxigenic fungi and their toxins formation. Ph. D. Thesis, Botany Dept. Faculty of Science, Assiut Univ., Egypt.

32. Peltonen K, el-Nezami H, Haskard C, Ahokas J, Salminen S (2001) Aflatoxin $\mathrm{B} 1$ binding by dairy strains of lactic acid bacteria an d bifidobacteria. $\mathrm{J}$ Dairy Sci 84: 2152-2156.

33. Haskard CA, El-Nezami HS, Kankaanpää PE, Salminen S, Ahokas JT (2001) Surface binding of aflatoxin $\mathrm{B}(1)$ by lactic acid bacteria. Appl Environ Microbio 67: 3086-3091.

34. El-Nezami H, Polychronaki N, Salminen S, Mykkänen H (2002) Binding rather than metabolism may explain the interaction of two food-Grade Lactobacillus strains with zearalenone and its derivative (')alpha-earalenol. Appl Environ Microbiol 68: 3545-3549.

35. El-Nezami H, Salminen S, Ahokas J (1996) Biological control of food carcinogen using Lactobacillus GG. Nutr Today 31: 41-42.

36. Morotomi M, Mutai M (1986) In vitro binding of potent mutagenic pyrolysates to intestinal bacteria. J Natl Cancer Inst 77: 195-201.

37. Tanabe T, Otani H, Osono A (1991) Binding of mutagens with cell wall peptidoglycan of Leuconostoc mesentroides subsp. Dextranicum T 180. Milchwissenschaft 46: 622-625.

38. Kollarczik B, Gareis M, Hanelt M (1994) In vitro transformation of the Fusarium mycotoxins deoxynivalenol and zearalenone by the normal gut microflora of pigs. Nat Toxins 2: 105-110.

This article was originally published in a special issue, Food Toxicology and Food Borne Pathogens handled by Editor(s). Dr. Barakat S M Mahmoud, Mississippi State University, USA; Dr. Dike O Ukuku, FSIT-ERRC-ARS-USDA, USA 